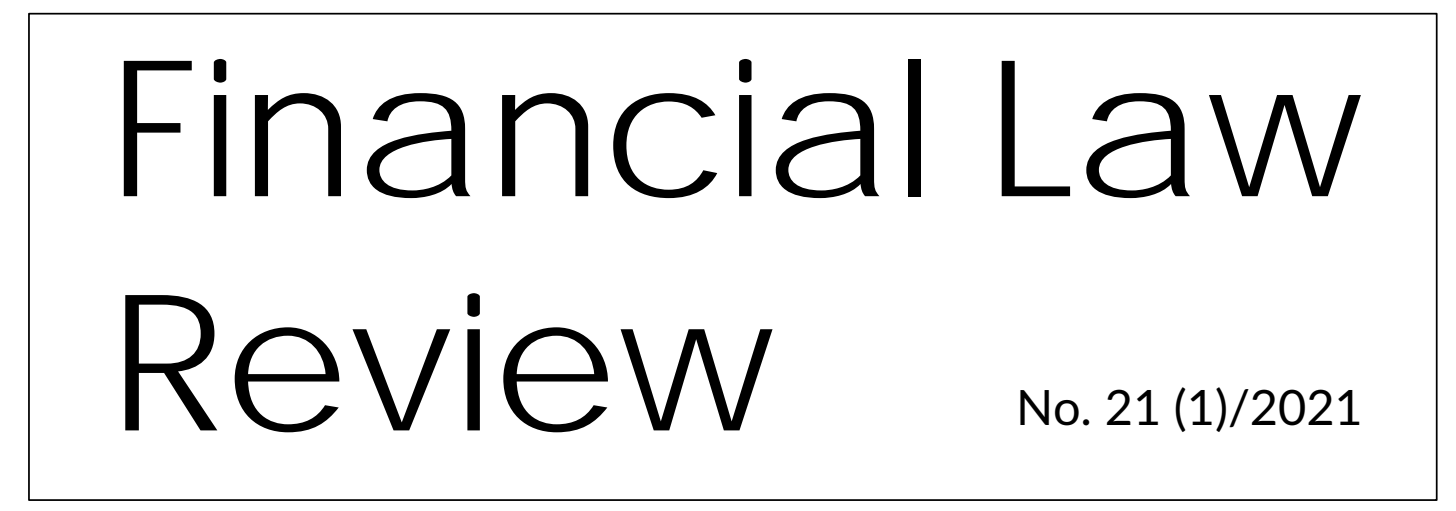

UNIVERSITY OF GDAŃSK • MASARYK UNIVERSITY • PAVEL JOZEF ŠAFÁRIK UNIVERSITY • UNIVERSITY OF VORONEZH http://www.ejoumals.eu/FLR

\title{
THE THEORY OF PLANNED BEHAVIOUR AS A RESEARCH TOOL IN CONNECTION WITH TAX LAW AND ECONOMICS
}

\begin{abstract}
The Theory of Planned Behaviour (TPB) is a theory from the field of psychology that was developed by Icek Ajzen in 1985 in order to predict and change human behavior. The theory works with three basic inputs concerning the studied behavior of the person. These then lead to an intention to behave in a certain way. Over the years the theory has been successfully applied to research in various fields.

By using the method of systematic review, deduction, induction and synthesis, the article looks into the use of the TPB research model in connection with tax law and economics.

One of the areas where tax law and economics meet is taxes. Hence the aim of the article is to confirm or disapprove the hypothesis that firstly TPB has been used in connection with taxes over the last ten years. If this hypothesis is confirmed then it is the aim to determine in which areas it has been applied. Secondly to confirm or disapprove the hypothesis that TPB has been used in connection with taxes in all seven world regions as divided by the World Bank. If that hypothesis is correct the aim is to determine how it has been applied in the Czech Republic and with what results.
\end{abstract}

\footnotetext{
* Jana Bellova: senior lecturer, Palacky University Olomouc, department of Political and Social Sciences, 17. listopadu 8, 77111 Olomouc, Czech Republic, e-mail: jana.bellova@upol.cz, ORCID: 0000-0002-5006-6273.

** Tatána Špírková: senior lecturer, Palacky University Olomouc, department of Administrative and Financial Law, 17. listopadu 8, 77111 Olomouc, Czech Republic, e-mail : tatana.spirkova@upol.cz, ORCID: 0000-0002-9728-8308.
} 
Key words: theory of planned behavior, tax compliance.

JEL Classification: K34

\section{Introduction}

Taxes, fees and other similar contributions are the most important and the most extensive income of the public budgets. Without these payments the public budgets would lose a significant part of its income and would not be able to function adequately. It can be stated that these contributions represent for the state the basic condition for its existence [Boháč, Radvan 2015: 36-39]. Tax and duty must be stated in the law clearly and comprehensively. Would this not happen, this insufficiency should not create a burden for an individual but its consequences should be borne by the state that creates these for actions. Not every interpretive ambiguity though can lead to this choice of interpretation which is the most favourable for the tax subject. In an imaginary competition of the interpretative rules it is only the "comparably convincing interpretative alternatives" that are constructed [Šimka, Nováková 2015: 7-14]. This legal anchoring of taxes and fees has its roots in article 11, paragraph 5 of the Charter of Fundamental Rights and Freedoms that states that taxes and fees can be levied only by a legal act. This formal provision of the law is connected with the protection of certain institutes against the interventions of executive power and is hence connected with the question of the division of power [Karfíková 2018: 7-19]. The provision of the law based on the latest case law of the Supreme Administrative Court is interpreted in the way that all significant features must be stated in the legal act and it is completely unacceptable that the subject of taxation was specified in any other way such as for example by an implementing decree of the Ministry of Finance. In such a case the constitutional principle of the division of power would be violated [Verdict of the Supreme Administrative Court nb. 5 Afs 45/2011 - 94]. Within the concept of the Theory of Planned behaviour this can be looked as the base that creates the social pressure at the individual towards the desired behaviour as anchored by the legal norms

The current financial science views taxes in their interconnectivity with the whole economy and gives them the same functions that they fulfil in the sphere of public finances: allocative function, redistributive function and function of stabilization. Since the times of Adam Smith not many requirements laid on a good tax system have altered and the criteria have incorporated equity, efficiency, tax stimulus, correct influence on the macroeconomic aggregators and last but not the least perfection and political clarity [Kubátová 2018: 41-42]. All these requirements and their adequate carrying out then 
influence the perception of tax payments as a desired behaviour of the tax subject in the concept of the Theory of Planned Behavior. They influence individual's attitudes towards the payment or avoidance of the payment (attitude towards the behaviour) and also the perception by the society of which the individual is a part of (subjective norm). The way to set the actual system of tax collection then represents the last aspect of the perceived control over the behaviour which then characterizes the level to which the defined behaviour can be carried out in the sense of means or hurdles. According to Široký [Široký 2016: 34-35] the basic generally accepted and valued principles the principles of tax equity and the principle of tax efficiency. It is also necessary to realize that satisfaction of taxes to all of the above mentioned principles has its limitations. The current fulfilment of all the principles is not feasible in reality as a result of disproportional tax collection costs as well as the possible contrast in the individual principles Vítek [Vítek 2019: 9-13] contributes by stating that the tax policy as the configuration of the tax system in the widest sense of the word migrates between two main goals being the tax equity and tax efficiency that are very difficult to harmonize due to the fact that it reflects the political preferences that more or less change after each election. Nevertheless, it would be useful to establish a long term agreement on these basic principles of that would contribute to higher tax stability and thereby to the limitation of tax collection costs of both state and tax payers.

The principle of tax equity is then one of the two basic principles of the modern tax system. In the area of economics, it is of course difficult to express what each of the principles means precisely hence a narrower point of view is defined that being the distribution of wealth through the tax system. In other words, based on the mayoral point of view in developed countries the wealth is redistributed from rich to poor. In what way the taxes then redistribute the wealth and can be measured by various tools and indicators such as Lorenz's curve or Gini's coefficient [Vítek 2019: 9-13]. Within the framework of tax equity, the tax incidence is then also evaluated that is at whom the tax is then levied throughout the change in prices. In the area of law, the principle of tax equity can be also noticed in the case law of courts. For example, the Supreme Administrative Court in its ruling from 24th February 2004 stated: "The current state has to be perceived as a result of a social contract that is an implicit consensus of the society about the fact that it is the rational existence of an institute insuring public interests. Hence though the state has a position of a superior authority in many interactions, its primary essence is based on the contractual basis. That above other means that each individual and legal entity has not only many obligations towards the state (these can be summed up under the obligation to respect its legal system) but also many rights. Looked at from this point of view the tax system represents not only a 
necessary means to the material existence of the state but also some kind of legitimacy test of the institution of the state. Hence the tax system must be from the point of view of its concept as well as concrete application transparent, predictable and adequate" [Verdict of the Supreme Administrative Court, nb. 2 Afs 62/2004-70].

In real life the tax policy of the state of course does not focus only on tax efficiency and tax equity but the tax policy is also tied to stimulation or discouragement of certain behaviour in individual areas. The tools that are then used by tax policy include various tax rates, tax exemptions or subject tax exemption, tax relief or deviations of the process level of tax payments. Tax policy and its analysis then must come to terms with the questions of the setup of the tax administration and the fulfilment of tax duties. These do not only include the institutional and procedural setup of tax offices (from the point of view of their efficiency and effectivity) but also the system of motivation and demotivation of the taxpayers supporting the fulfilment of the tax obligations. It is this last topic that is on the verge of several research fields such as law, public administration and economics [Vítek 2019: 9 - 13]. The last but not the least field of research that can play its part in tax policy is psychology and its research concerning the individual attitudes of tax subjects.

This article deals with the question whether the psychological Theory of Planned Behavior (TPB) has been previously used in the context of tax law and is then able to provide a research tool to understand attitudes of the tax payers to their tax duties.

The paper is structured as follows: after the Introduction there is a chapter called The Theory of Planned Behavior in connection with tax law followed by the chapter on the Presentation of Findings leading to the Conclusion.

\section{The Theory of Planned Behavior in Connection with Tax Law}

The theory of Planned Behavior generally represents a significant and predictive tool that is not questioned. The results of a large amount of studies confirm the ability of TPB to predict positive as well as negative attitudes towards certain behaviour in the future. Up till 1996 there were 56 published studies that showed the predictive significance of an intention to behave in a certain way. Also later comprehensive studies and meta-analysis proved the predictive importance of various intentions. There are also researchers in the Czech Republic using the TPB as their research tool in various areas of application.

The theory was developed by Icek Ajzen in 1985 is a widely applied behavioral model. It helps understand human behaviour and how to change it. The TPB model details how the 
influences upon an individual determine the individual's decision to follow a particular behavior.

This theory over the years has been most successfully and most extensively used in health related behaviour in order to predict and change people's behaviour towards the desired one such as e.g. promotion of condom use [Albarracin et al. 2001: 142-161], leisure [Ajzen et al. 1992: 207-224], exercise [Nguyen et al. 1997: 233-246], diet [Conner et al. 2003: 1978S-1982S], non-smoking or use of e-cigarettes [Sniehotta 2009: 257-270].

According to the TPB, any action a person takes is guided by three types of considerations: behavioral beliefs (beliefs about the probable consequences of the practiced behavior), normative beliefs (beliefs about the normative expectations of other people), and control beliefs (beliefs about the presence of factors that may enable or obstruct the performance of the behavior).

Behavioral beliefs normally result in a favorable or unfavorable attitude toward a specific behavior, normative beliefs result in perceived social pressure or subjective norms, and control beliefs trigger perceived behavioral control. Usually, the greater the favorable behavior, subjective norm, and perceived control, the stronger the person's intention to perform the behavior in question.

Within the TPB, the determinants of behavior are intentions to engage in that behavior and perceived behavioral control over that behavior. Intentions represent a person's motivation. The construct is conceptualized as an individual's conscious plan or decision to exert effort in order to engage in a particular behavior. Perceived behavioral control is a person's expectancy that performance of the behavior is within his/her control.

Intentions are determined by three variables. Firstly, it is the attitude towards behavior, which is an individual's overall evaluation of the behaviour. Secondly, it is the subjective norms, which consist of a person's beliefs about whether significant others think he/she should engage in the behaviour and thirdly, it is the perceived behavioral norm. This measures the extent to which the individual perceives that the behavior is under their personal control.

The attitude, subjective norm and perceived behavioural norm components are determined by underlying beliefs. Attitude is a function of a person's salient behavioral beliefs; which represent perceived likely consequences of the behavior. A subjective norm is a function of normative beliefs, which represent perceptions of specific salient others' preferences about whether one should or should not engage in a behaviour. A perceived behavioural 
norm is based on beliefs concerning access to the necessary resources and opportunities to perform the behavior successfully.

So, according to the TPB, individuals are likely to engage in a behavior if they believe that the behavior will lead to particular outcomes which they value, if they believe that people whose views they value think they should carry out the behavior, and if they feel that they have the necessary resources and opportunities to perform the behavior.

Hence perceived behavioral control determines both intentions (together with attitudes to behavior and subjective norms) and behavior (together with intentions). The joint determination of intentions is straightforward: it is assumed that when individuals form intentions they take into account how much control they have over the behavior. The joint determination of behavior (together with intention) can be understood in two ways. The first relates to motivation: an individual who has high perceived behavioral control and who has formed the intention to do something will simply try harder to carry out that action than someone with an equally strong intention but who has lower perceived behavioral control. The second explanation assumes that when someone has the intention to perform a behavior and fails to act on that intention, this failure is attributable to his or her lack of control over the behavior. The role of perceived behavioral control here is 'nonpsychological' in the sense that it is not the perception of control that causes the failure to act in accordance with intentions; rather, it is a lack of actual control.

This can be illustrated by Icek Ajzen's own scheme:

Scheme 1: Theory of Planned Behavior

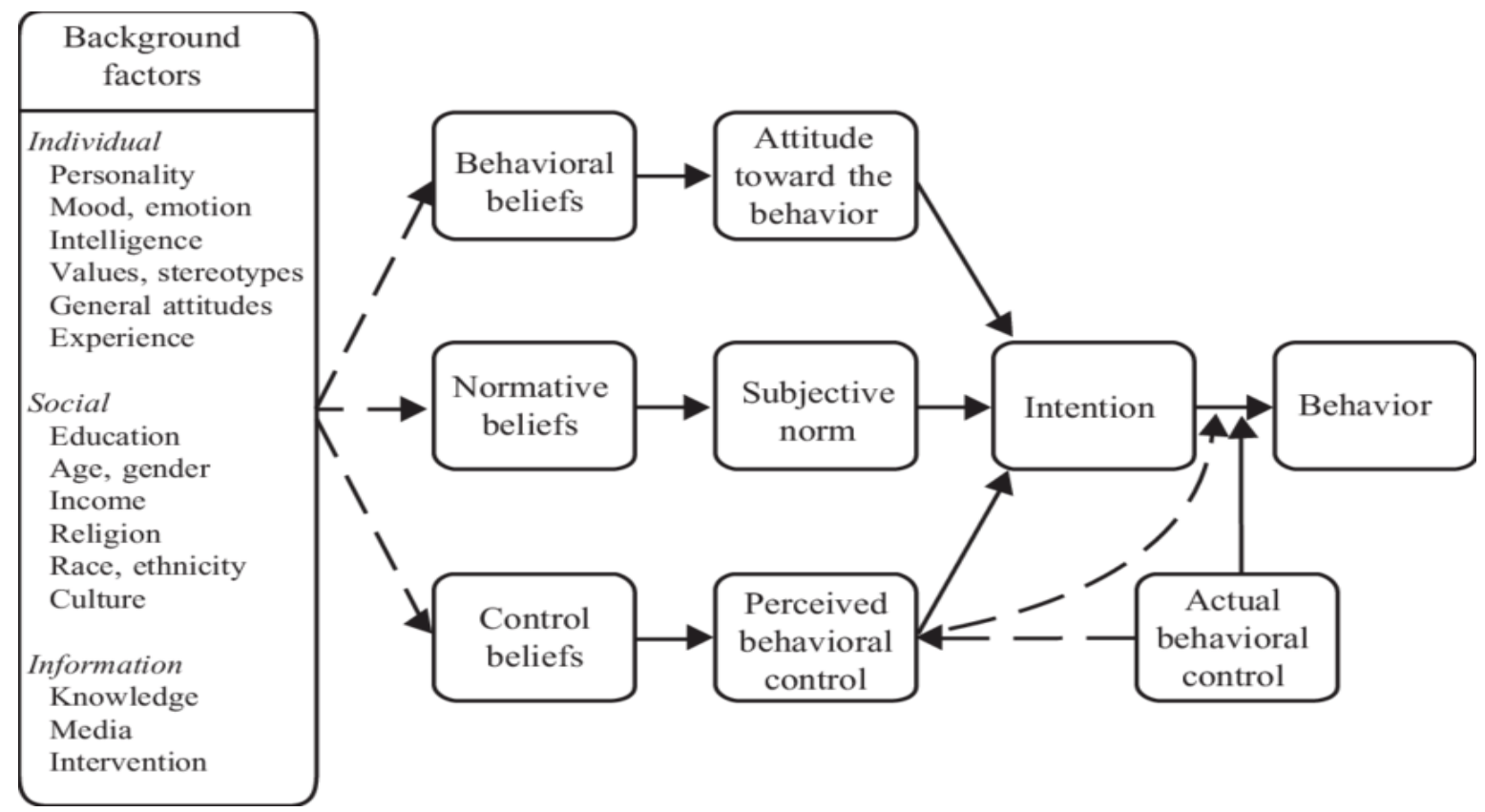

Source: Ajzen 2005, fig. 5. 


\section{Presentation of Findings}

The aim of the article was to find out whether the theory has been used in the area of tax law and if so how and with what outcomes.

In order to do that the following hypothesis to confirm or disapprove were established:

1. TPB has been used in connection with tax law over the last ten years - if this hypothesis was confirmed then the aim was to determine in which areas it has been applied.

2. TPB has been used in connection with tax law in all seven world regions as divided by the World Bank which recognizes the following seven world regions: East Asia and Pacific, Europe and Central Asia, Latin America and Caribbean, Middle East and North Africa, North America, South Asia, Sub-Saharan Africa - if this hypothesis was confirmed then the aim is to determine how it has been applied in the Czech Republic and with what results.

In order to confirm or disapprove these hypotheses a systematic review of the available eresources of the Palacký University Olomouc library was carried out with the search words of the theory of planned behaviour, taxation and taxes. The results were also limited by the time period of 2010 to 2020, English language and full text.

The results confirmed the first hypothesis that TPB has been used in connection with tax law over the last ten years, it has been proved to be a useful tool in research and the fields of research were tax compliance and on-line tax filing.

The results disapproved the second hypothesis that TPB has been used in connection with taxes over the last ten years in all seven world regions and it has also disapproved that it has not been previously used in the Czech Republic in connection with tax law.

The results of the systematic review were the following:

1. A total of nine studies were available and matched the criteria.

2. There were only two areas of application of TPB in connection with tax law - tax compliance (three studies) and on-line tax filling (six studies).

3. These studies were carried out in the following world regions:

- East Asia and Pacific region - Malaysia - one study [Tallaha 2014: 40, 91101], Indonesia - three studies [Marthadiansyah 2013: 23-32], [Bramantyo 2020: 5(101)], [Hery, Jasman 2019: 9(93)], Taiwan - one study [Lu 2010: 800-810].

- North America - USA - one study [Bobek 2013: 115, 451-468]. 
- South Asia - India - two studies [Maji, Pal 2017: 46-66], [Shukla, Kumar 2019: 44(3) 99-114].

- Middle East and North Africa - Iran -one study [Parsaei 2013: 10 (9s)].

4. No evidence of the application of TPB in connection with taxes has been found in Europe and Central Asia region, Latin America and Caribbean or Sub-Saharan Africa.

Based on the findings we have decided to look closer at one of the applied areas which seemed more interesting to us from the attitude towards a certain behaviour point of view and that was the area of tax compliance.

As it has already been stated above, as a result of the systematic review three studies concerning the application of the TPB in connection with tax compliance were carried out between the years 2010 and 2020 .

The first study [Bobek 2013: 115, 451-468] was carried out in the USA. The authors believe that the loss in income tax due to taxpayer non-compliance was mostly due to under-reporting of the individual income tax. The aim of the article was to explore the role of the social norm in tax compliance. In order to do that it was necessary to draw on the social norms theory to clarify both the definition and the influence of social norms on tax compliance behaviour. Based on the theory of social norms social norms are rules and standards that are understood by members of a group, and that guide and/or constrain social behaviour without the force of law. There are four different types of norms: descriptive norms, injunctive norms, subjective norms and personal norms (defined as individuals' standards for behavioural/ethical beliefs). In order to do that the authors investigated the effect of social norms using a hypothetical compliance scenario with 174 experienced taxpayers and participants. The research showed that social norms have an important direct as well as indirect influence on tax compliance behaviour and research confirms the important role of social norms with regard to the taxpayer's compliance behavior.

The results showed [Bobek 2013: 115, 451-468] that while having significant resources of enforcement, an increase in voluntary compliance is the key to reducing the tax gap. While social norm constructs were significantly correlated with tax compliance intentions, path analysis indicated that only subjective norms and personal norms directly affected taxpayer's compliance intentions. Thus a conclusion was reached that in a setting where cheating is possible, personal and societal norms do indeed play a decisive role in tax compliance. Another important conclusion was that personal norms play a much stronger 
role than any other type. Analytical studies suggest that favourable social norms are dependent upon a reasonable level of enforcement and the tax morale literature has identified a negative relationship between tax moral and the shadow economy. Understanding how external actions can influence social norms may be critical to increasing and maintaining compliance levels and reducing the tax gap. Further researches may also wish to examine how social norms are affected by specific governmental actions or policy. Similarly, all taxes are not viewed the same by taxpayers and this may affect the likelihood that they pay the tax. Some may be perceived to be "good" (e.g. income taxes) while others may be perceived to be "bad" (e.g. sales tax on internet purchases in the U.S.). Further research should also consider different tax laws with different propensities to cheat (e.g. earned income credit, home office deduction) and examine broader samples. The results may be helpful to policy makers and tax researchers who are interested in improving compliance [Bobek 2013: 115, 451-468].

The second study [Marthadiansyah 2013: 23-32] was carried out in Indonesia and it used 181 taxpayers. The aim of the study was to analyse factors that influence taxpayer's compliance intention to file an annual income tax return. That is to analyse the effect of attitude (defined by the TPB as an individual's evaluation of favorableness or unfavorableness of an attitude object), subjective norms (defined by the TPB as a person's beliefs about whether specific individuals or groups approve or disapprove of an individual performing a specific behaviour), perceived behavioral control (defined by the TPB as a degree of control an individual perceives he/she has to engage in a particular behaviour) and moral intention to comply in filing annual income tax return. This study found morals to be important in compliance. The analyses of the questionnaires filled in by the participants found that perceived behavioral control and morals positively influence the compliance intention of taxpayers in filing annual income tax returns. The attitude to comply and subjective norms have a significant statistical effect. Taxpayer compliance can effect tax revenue where the low taxpayer compliance will cause a reduction in tax revenue. Taxpayer compliance can affect the success of the collection effort of tax revenue. The taxpayer who has a high degree of moral belief will have the intention to comply. The next variable, which also has a significant effect on a taxpayer's intention to comply, is perceived behavioral control. Analysis showed that the perception of control about the probability of being tax audited, getting fines and sanction and reported by a third party have a significant effect on the intention to comply. Other significant findings are that there are no statistically significant relationships between attitude to comply and subjective norms and intention to comply. It means that the taxpayers perception about 
good or bad doesn't affect their intention to comply. It is the same for subjective norms, where social pressure on the taxpayer doesn't affect a taxpayer's intention to comply.

The third study [Hery, Jasman 2019: 9(93)] was also carried out in Indonesia. This study aimed to investigate the effect of perceived tax equity (fairness), normative expectation (social and moral norms) and legal sanctions (detection risk and penalty magnitude) toward tax compliance intentions. The sample used in this study consisted of 75 individual taxpayers. The results of this study show that equity perception (meaning the fairness perception) has a positive and significant effect on tax compliance intentions, detection risk (meaning the possibility of the tax authority detecting violations of tax regulations) does not affect tax compliance intentions, and penalty magnitude (defined as the value of fines or suffering due to sanctions and penalties related to the discovery of violation) has a positive and significant effect on tax compliance intentions. The study has also found that fulfilment of tax obligations must be in accordance with the applicable regulations without the need for inspection, careful investigation, warnings, threats and the application of sanctions in both law and administration. To achieve high compliance not only does the authority of the government have to be strengthened but also the trust of people in the government must be built. Therefore, it can be concluded that the compliance of taxpayers in fulfilling their tax obligations is closely related to their compliance with the applicable tax regulations. The results of the study prove that the TPB can be used to predict the factors (determinants) that influence taxpayers compliance behaviour and also that a good taxation system will create a conducive environment for taxpayers to fulfil their tax obligations voluntarily without the need for examinations, investigations, warnings, threats or the application of administrative or legal sanctions [Hery, Jasman 2019: 9(93)].

\section{Conclusion}

The results of the studies show that the Theory of Planned Behavior as presented by Ajzen is a model that is able to predict the future behavior and has the ability to influence this behavior in both positive as well as negative way. This prediction can be done based ont the measurements of attitudes, subjective norms and perceived control that then together lead to the power of the intention towards the given behavior in the respect that whether the person is or is not going to participate in the behavior. There is reason why this theory could not be applied also to behavior of tax subject in the area of taxes. Such studies have been carried out abroad during the selected years. 
So far there has been no such study aimed at the behavior of tax subjects carried out in the Czech Republic though there have been studies using this theory applied in other spheres such as psychology [Příhodová, Preiss 2019: 39-49].

Tax law relations as an object of possible research are the essence of public law where on one side it is the state that collects the taxes and on the other side it is the individual who has created values from which they have to pay tax. And who in the end often does not get any reimbursement for them [Šimka, Nováková 2015: 7-14]. According to Šimka [Šimka 2015: 40-42] the modern tax system is influenced by the many complexities of the modern age. Modern society is a society based on impersonal, anonymous mechanisms and procedures. It is based on purpose-designed and in a way cold rationality where less and less rules, values and procedures in it are self-evident and clearly recognized by the individuals. It is a society with a very low consensus about how the rules of law and tax law above all should look. It is possible to speak about the naturally perceived equity of taxes only very rarely, taxes are political, technical, changeable, and dependent on the instantaneous success of one or another social or political group. Karfíková [Karfíková 2018: 17] states that tax law has incorporated a certain level of endeavor of the addressees to bypass the rules. The principles of tax equity and tax equality on the one side and predictability and legal security on the other side get into a state of a certain tension. It is this conflict that represents the problem when the modern state must deal with concrete forms of unwanted behavior. On the other side based on the ideas of Boháč and Radvan [Boháč, Radvan 2015: 36 -39] the perception of taxes should not be seen as the limitation of legal ownership but as a payment by which the taxpayer contributes to public matters. It is then understood by such a person that the payment of taxes is to become an expenditure of the public budgets and is to be used for expenditures for which there should be a social consensus. In this context the obligation to pay taxes, fees and other similar contributions should be an honor.

The above mentioned ideas can actually be looked at as attitudes towards the individual determinants of Ajzen's Theory of Planned Behavior. In case of Šimek it is the role of the social pressure towards the behavior, in case of Karfíková, it is the opinion of various internal attitudes leading towards an undesired behavior and at last but not least in case of Radvan and Bohác it is the question of personal moral, honour that can also be found in the perception of attitude of the given individual towards the behavior and his or her evaluation and perception of the behavior as positive or negative. Should the attitude mentioned by Radvan and Boháč spread among the majority of population it would then become a social norm from the point of view of the Theory of Planned Behavior and would 
incorporate the social pressure towards the desired behavior. The above mentioned researchers do not work with Ajzen's Theory of Planned Behavior as a tool, it was our idea to use their research results as an illustration of the fact that within the tax law the researchers are currently trying to identify the individual determinants of the desired or undesired behavior and present their personal opinions on what influences the behavior of tax subjects.

What then is the role of the inner attitudes of the taxpayers towards their behavior in tax law relations? In what way is it the social or legal pressure through legal norms and their enforcement that form their required behavior?

Further studies working with the presented Theory of Planned Behavior applied in the area of tax law could help answer the questions above. Let us repeat that the factors influencing human behavior based on the theory consist of attitudes, subjective norms, perceived behavioral control, intention and the actual behavior. Some of these have been researched in more depth in the three presented studies. With the first study we could sum up that it is the role of voluntary motivation that is fundamental for the intention of the taxpayers to fulfill their obligations. This seems to be very much in accordance with Boháč's and Radvan's ideas on taxpayers' behavior as an honor. On the other hand, it was the subjective norms being represented by social and therefor legal pressure through law enforcement and the system of sanctions in accordance with the findings of the second study. The third study then highlights the role of internal attitudes but also the necessary existence of sufficient sanctions within the influence on the behavior of the taxpayers.

It is our belief that it would be beneficial to carry out similar research in the Czech Republic using the Theory of Planned Behavior as a research tool in tax law, in concrete in tax compliance and it would be beneficial to present its outcomes reflecting the current state of our tax system and factors influencing the behavior of taxpayers. Based on the results of the findings and our own interpretation of the findings it is our opinion that it would be useful to carry out a similar research in the Czech Republic as was carried out by Bobek et al. as mentioned in the first study and use it as a research template. The Czech Republic has closer legal system framework and tax mentality of the tax payers than Indonesia. We would recommend to apply the TPB to direct taxes such as personal income tax and corporate income tax as these show the most room for application of any tax compliance strategies. Having said that it does not necessarily mean that we believe that this is the most efficient way to carry out a further research. As we mention later on in limitations of the article, it may just as well be the case that there are other research tools such as TPB 
that have been successfully used in connection with tax compliance in the past and have proven to be more efficient. It is important to bear in mind that the purpose of this article was to determine if the TPB has been used as a research tool in connection with taxes and not to see what other research tools there might have been. We have found out that this has been done though not in the Czech Republic, more clearly, that it has been done so in connection with tax compliance. Now we believe that it would be rather beneficial to find out whether there have been other research tools that have been successfully used in connection with tax compliance and then decide which of these research tools would be accurate appropriate and would get better research results. Having looked very briefly into that we have already established that there are other research tools such as e.g. "nudging" or "prospect theory's value function" and it is rather likely that there are other ones.

It is our opinion that for further research we should look into what other theories have been successfully applied in connection with tax compliance around the world and based on that choose the most up to date method of further research of tax compliance in connection with personal income tax or corporate income tax in the Czech republic where based on our findings no such research has been carried out with the use of TPB but don't know yet whether it has been done in connection with different research tools.

There are limitations to the research and its findings. Firstly it is time limitation, it is possible that significant research in this area was carried out earlier than 2010. As to this limitation, we can but say that we wanted this research to be as up to date as possible. Secondly, it is the question of the language. It is possible though unlikely that significant research in this area has been carried out in other languages. Thirdly the choice of search words. Theory of planned behaviour was an obvious choice, the other two were taxation and taxes in order to get as near to the search word as possible. It should be admitted that though the idea was to narrow the search it could have omitted some outcomes. Fourthly the search was narrowed to the TPB but it is possible that other theories have been used and perhaps more successfully in the area of tax law. The last was our assumption that there was or is a need to understand and change people's behaviour in connection with taxes and tax law. 


\section{References}

Ajzen, I.: The Influence of Attitudes on Behavior (in:) Albarracín, D., Johnson B. T., Zanna P. (eds.), The handbook of attitudes, New Yor: Lawrence Erlbaum Associates, 2005.

Available at: https://www.researchgate.net/figure/The-theories-of-reasoned-action-andplanned-behavior_fig3_264000974, accessed: $7^{\text {th }}$ July 2020.

Ajzen, I., Driver, B. L. Application of the theory of planned behavior to leisure choice.

Available at: https://doi.org/10.1080/00222216.1992.11969889, accessed: $7^{\text {th }}$ July 2020.

Albarracin, D et al. Theories of reasoned action and planned behavior as models of common use: a meta-analysis.

Available at: https://www.ncbi.nlm.nih.gov/pmc/articles/PMC4780418/, accessed: 7th July 2020.

Bobek, D. D. et al. Analysing the role of social norms in tax compliance.

Available at: http://hdl.handle.net/10.1007/s10551-012-1390-7, accessed: 8th July 2020.

Boháč, R., Radvan M.: Vnímání daní, poplatků a jiných obdobných peněžitých plnění ve světle jejich ústavních aspektů. [Perception of taxes, fees and other similar monetary contributions in the light of their constitutional aspects] Bulletin komory daňových poradců České republiky, [Bulletion of the association of tax advisors of the Czech Republic], nb. 2, [36-39], 2015.

Bramantyo, S., A. Determinants of e-tax system acceptance by users.

Available at:

https://www.researchgate.net/publication/341657695_DETERMINANTS_OF_E-

TAX_SYSTEM_ACCEPTANCE_BY_USERS, accessed: $5^{\text {th }}$ July 2020.

Conner, M. et al. J. H. Environmental influences: factors influencing a woman's decision to use dietary supplements.

Available at: https://europepmc.org/article/med/12771349, accessed: $7^{\text {th }}$ July 2020.

Hery, H., Jasman, J. Factors affecting compliance with tax regulations: a theory of planned behavior analysis.

Available at: $\quad$ https://cyberleninka.ru/article/n/factors-affecting-compliance-with-taxregulations-a-theory-of-planned-behavior-analysis/viewer, accessed: 10 th July 2020.

Karfíková, M. Daně jako nástroj fungování státu. [Taxes as an instrument for state functioning], AUC IURIDICA. nb. 1.2018

Available at: https://docplayer.cz/106448294-Dane-jako-nastroj-fungovani-statu.html, accessed: $19^{\text {th }}$ July 2020.

Kubátová, K. Daňová teorie a politika. [Tax theory and policy]. Praha: Wolters Kluwer, 2018.

$\mathrm{Lu}$, Ch. et al. An empirical study of on-line tax filling acceptance model: integrating TAM and TPB.

Available at:

https://www.researchgate.net/publication/267839012_An_empirical_study_of_on-

line_tax_filing_acceptance_model_Integrating_TAM_and_TPB, accessed: $10^{\text {th }}$ July 2020.

Maji, S., K, Pal, K. Factors affecting the adoption of e-filling of Income tax returns in India: A survey. Available at:

https://www.researchgate.net/publication/315642164_Factors_Affecting_the_Adoption_of_ e-Filing_of_Income_Tax_Returns_in_India_A_Survey, accessed: $3^{\text {rd }}$ July 2020.

Marthadiansyah et al. Empirical study of tax payer compliance with tax filling: applying theory of planned behavior.

Available at:

https://www.researchgate.net/publication/268459316_EMPIRICAL_STUDY_OF_TAX_PAYE

R_COMPLIANCE_IN_TAX_FILING_APPLYING_THEORY_OF_PLANNED_BEHAVIOR, accessed: $5^{\text {th }}$ July 2020.

Nguyen, M. N. et al. Regular exercise in 30-to 60-year-old men: Combining the stages-of-change model and the theory of planned behavior to identify determinants for targeting heart health interventions.

Available at: https://pubmed.ncbi.nlm.nih.gov/9247847/, accessed: $7^{\text {th }}$ July 2020.

Parsaei, A. P. et al. Feasibility of online taxation using TPB and TAM.

Available at: http://www.lifesciencesite.com/Isj/life1004/, accessed: $4^{\text {th }}$ July 2020.

Příhodová, T., Preiss, M. Teorie plánovaného chování a její využití ve výzkumu. [Theory of Planned Behavior and ist use in research], Psychologie a její kontexty, [Psychology and ist contexts]. Available at: https://psychkont.osu.cz/fulltext/2019/2019-1-3-TS_Prihodova-Preiss.pdf, accessed: $18^{\text {th }}$ July 2020 . 
Shukla, S., Kumar, R. Role of trust in adoption of online good service tax filling in India.

Available at: https://journals.sagepub.com/doi/pdf/10.1177/0256090919877333, accessed: $4^{\text {th July } 2020 .}$

Sniehotta, F.F. An experimental test of the Theory of Planned Behavior. Available at: $\quad$ https://iaap-journals.onlinelibrary.wiley.com/doi/abs/10.1111/j.17580854.2009.01013.x, accessed: $7^{\text {th }}$ July 2020.

Šimka, K, Nováková, P.: Ústavní právo a daně. [Constitutional law and taxes], Bulletin komory daňových poradců České republiky,[Bulletion of the association of tax advisors of the Czech Republic], nb. 2, [7-14], 2015.

Šimka, K: Obrana principu „in dubio pro libertate“. [Protection of the principle „in dubio pro libertate"] Bulletin komory daňových poradců České republiky, [Bulletion of the association of tax advisors of the Czech Republic], nb. 2, [40-42], 2015.

Široký, J. Základy daňové teorie s praktickými přiklady. [Basic tax theory with practical examples]. Praha: Wolters Kluwer, 2016.

Vítek, L.: Ekonomie daňové politiky vyspělých zemí. [Economics of tax policy in developed countries], Bulletin komory daňových poradců České republiky, [Bulletion of the association of tax advisors of the Czech Republic], nb. 1, [9-3], 2019.

Tallaha, A., M. et al. Factors influencing e-filling usage among Malaysian taxpayers: Does tax knowledge matter?

Available at:

https://pdfs.semanticscholar.org/d236/63857c962e34335507541adae83e3246730d.pdf, accessed: $7^{\text {th }}$ July 2020.

Zimmerman, L. et al. The theory of planned behavior and the earned income tax credit.

Available at:

https://newprairiepress.org/cgi/viewcontent.cgi?referer=https://www.google.com/\&httpsre dir $=1 \&$ article $=1066 \&$ context=jft, accessed: $6^{\text {th }}$ July 2020 .

\section{Court Rulings}

NSS [Supreme Administrative Court] of Brno ruling 12th January 2006, nb. 5 Afs 45/2011 - 94

NSS [Supreme Administrative Court] of Brno ruling 24th February 2005, nb. 2 Afs 62/2004-70.

\section{Internet Resources}

Theory of Planned Behavior - an overview

Available at:

https://www.sciencedirect.com/topics/medicine-and-dentistry/theory-of-plannedbehavior/pdf, accessed: $7^{\text {th }}$ July 2020.

The World by Region

Available at:

http://datatopics.worldbank.org/sdgatlas/the-world-by-region.html, accessed: $7^{\text {th }}$ July 2020. 